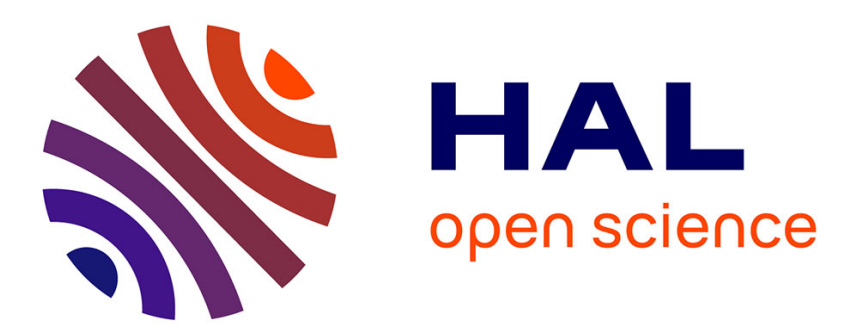

\title{
Beyond the Cut Hunter: A Historical Epidemiology of HIV Beginnings in Central Africa
}

Stephanie Rupp, Philippe Ambata, Victor Narat, Tamara Giles-Vernick

\section{To cite this version:}

Stephanie Rupp, Philippe Ambata, Victor Narat, Tamara Giles-Vernick. Beyond the Cut Hunter: A Historical Epidemiology of HIV Beginnings in Central Africa. EcoHealth, 2016, 13 (4), pp.661-671. 10.1007/s10393-016-1189-6 . hal-02159241

\section{HAL Id: hal-02159241 https://hal.science/hal-02159241}

Submitted on 16 Sep 2019

HAL is a multi-disciplinary open access archive for the deposit and dissemination of scientific research documents, whether they are published or not. The documents may come from teaching and research institutions in France or abroad, or from public or private research centers.
L'archive ouverte pluridisciplinaire HAL, est destinée au dépôt et à la diffusion de documents scientifiques de niveau recherche, publiés ou non, émanant des établissements d'enseignement et de recherche français ou étrangers, des laboratoires publics ou privés. 


\title{
Original Contribution
}

\section{Beyond the Cut Hunter: A Historical Epidemiology of HIV Beginnings in Central Africa}

\author{
Stephanie Rupp, ${ }^{1}$ Philippe Ambata, ${ }^{2}$ Victor Narat, ${ }^{3}$ and Tamara Giles-Vernick ${ }^{3,4}$ \\ ${ }^{1}$ Department of Anthropology, City University of New York - Lehman College, New York, NY \\ ${ }^{2}$ Ministry of Agriculture and Rural Development, Yaoundé, Cameroon \\ ${ }^{3}$ Emerging Diseases Epidemiology Unit, Institut Pasteur-Paris, 25-28 Rue du Docteur Roux, 75724 Paris Cedex, France \\ ${ }^{4}$ Canadian Institute for Advanced Studies, Toronto, Canada
}

\begin{abstract}
In the absence of direct evidence, an imagined "cut hunter" stands in for the index patient of pandemic HIV/AIDS. During the early years of colonial rule, this explanation goes, a hunter was cut or injured from hunting or butchering a chimpanzee infected with simian immunodeficiency virus, resulting in the first sustained human infection with the virus that would emerge as HIV-1M. We argue here that the "cut hunter" relies on a historical misunderstanding and ecological oversimplification of human-chimpanzee (Pan Troglodytes troglodytes) interactions that facilitated pathogenic transmission. This initial host shift cannot explain the beginnings of the HIV/AIDS pandemic. Instead, we must understand the processes by which the virus became transmissible, possibly between Sangha basin inhabitants and ultimately reached Kinshasa. A historical epidemiology of the late nineteenth and twentieth centuries, provides a much-needed corrective to the major shortcomings of the cut hunter. Based on 62 oral historical interviews conducted in southeastern Cameroon and archival research, we show that HIV emerged from ecological, economic, and socio-political transformations of the late nineteenth and twentieth centuries. The gradual imposition of colonial rule built on and reoriented ecologies and economies, and altered older patterns of mobility and sociality. Certain changes may have contributed to the initial viral host shift, but more importantly, facilitated the adaptation of HIV-1M to human-to-human transmission. Our evidence suggests that the most critical changes occurred after 1920. This argument has important implications for public health policy, underscoring recent work emphasizing alternative pathways for zoonotic spillovers into human beings.
\end{abstract}

Keywords: Africa, HIV, SIV, Disease emergence, Nonhuman primates, Historical epidemiology

\section{INTRODUCTION}

The "cut hunter," the purported index patient of pandemic HIV-1M, serves as an explanation for the first

Correspondence to: Tamara Giles-Vernick, e-mail: tamara.giles-vernick@pasteur.fr sustained cross-species transmission of a simian immunodeficiency virus (SIV) from nonhuman primates (NHPs) into a human being. According to this model, late nineteenth century European colonizers imported huge numbers of firearms, and one African hunter, profiting from this arms influx, was cut or injured by a chimpanzee infected with SIV; he then traveled down the Sangha river to 
Kinshasa and became the "Patient Zero" of the HIV/AIDS pandemic (Pepin 2011; Hahn et al. 2000; Chitnis et al. 2000; Worobey et al. 2008; Takehisa et al. 2009; De Souza et al. 2010; Peeters et al. 2014; Faria et al. 2014). Colonialism and firearms thus served as twin catalysts to the global pandemic, wresting equatorial Africans from their sedentary, isolated existence, and forcibly compelling them to supply the new colonial economy with forest resources, including hunting chimpanzees and other forest game with powerful new technologies.

The "cut hunter" model is based on the logical likelihood of SIV transmission through contact with bodily fluids, not on historical or clinical evidence. Some researchers suggest other transmission pathways (Locatelli and Peeters 2012; Peeters et al. 2014; Faria et al. 2014), but the predominant emphasis is on hunting as the source of infection. We argue that the cut hunter relies on ecological oversimplification and historical misunderstanding of human-chimpanzee (Pan Troglodytes trogolodytes) interactions that facilitated pathogenic transmission. SIVs are ancient viruses (Worobey et al. 2010), transmitted between NHPs through multiple pathways, not just hunting. As inhabitants of the Sangha basin forest for many thousands of years, human beings have occupied overlapping habitats with NHPs, competed for foraged resources, and hunted NHPs, including chimpanzees (Vansina 1990; Klieman 2003). Thus, there is no reason to assume that the first human exposure to SIV occurred during the colonial period. Moreover, this initial host shift cannot explain the beginnings of the HIV/AIDS pandemic. Instead, we must understand the processes by which the virus became transmissible between Sangha basin inhabitants and ultimately reached Kinshasa. A historical epidemiology of the late nineteenth and twentieth centuries provides a much-needed corrective to the major shortcomings of the cut hunter (Webb 2013).

We argue that HIV emerged as a result of ecological, economic, and socio-political transformations of the late nineteenth and twentieth centuries. Colonial rule reoriented ecologies and economies, altered older patterns of mobility and sociality, and introduced invasive medical procedures. The most critical changes occurred after 1920 and facilitated HIV-1M adaptation to human beings.

This argument is important because uncritical acceptance of the cut hunter makes for dangerous public health policy. The cut hunter has served as a template for more recent zoonotic disease emergence (Wolfe et al. 2005, 2007). Despite recent efforts to address other risk factors for zoonotic spillover, hunting and butchering continue to dominate explanations for cross-species infections (Paige et al. 2014; Mossoun et al. 2015; Johnson et al. 2015). Historical epidemiological investigations suggest other pathways for zoonotic spillovers into human beings that have practical significance for global health interventions.

\section{Beyond the "Cut Hunter"}

Phylogenetic analyses of HIV-1M and SIVcpz have given rise to numerous explanations of the virus's initial emergence in the central African middle Sangha river basin (Faria et al. 2014; Keele et al. 2006). These analyses indicate a chimpanzee-to-human transmission sometime between 1908 and 1933, but questions remain about when and how this transmission occurred.

Although hunting and butchering are high-risk activities that facilitate transmission through infected bodily fluids, the cut hunter has ecological and historical limitations. Phylogenetic analyses of different SIV strains reveal that they have long existed and circulated among NHPs (Worobey et al. 2010). Although some SIV transmissions between NHPs apparently result from hunting, others do not. SIV transmission from Chlorocebus sabaeus (Green monkey) to Erythrocebus patas (Patas monkey) evidently occurred because the two species are sympatric and engage in mutual grooming, delousing, and biting (Bibollet-Ruche et al. 1996). Although gorillas have been infected with chimpanzee SIV, they are not known to hunt or eat meat (Van Heuverswyn et al. 2006; Hofreiter et al. 2010). Because certain SIV transmissions cannot be traced to hunting, examining the range of contacts between humans and NHPs can yield insight into how SIVs and other microbes circulate.

From a historical perspective, the cut hunter narrative neglects the dynamic change among people, animals, forest resources, and microbes in central Africa's middle Sangha basin before colonization (Figure 1). It reproduces historical misconceptions that these societies were immobile, had no access to firearms, and did not hunt chimpanzees. Human habitation of this forest extends as far back as 40,000-35,000 B.P., and the establishment of forest villages and agriculture in present-day southern Cameroon date to the mid-to-late second millennium B.C.E. (Holl 1991, cited in Klieman 2003). Human hunting of chimpanzees and exposure to SIV is likely millennia-old. Bangando elders, one of the several forest societies inhabiting the region, recounted that their ancestors hunted chimpanzees with crossbows, spears, and traps. 


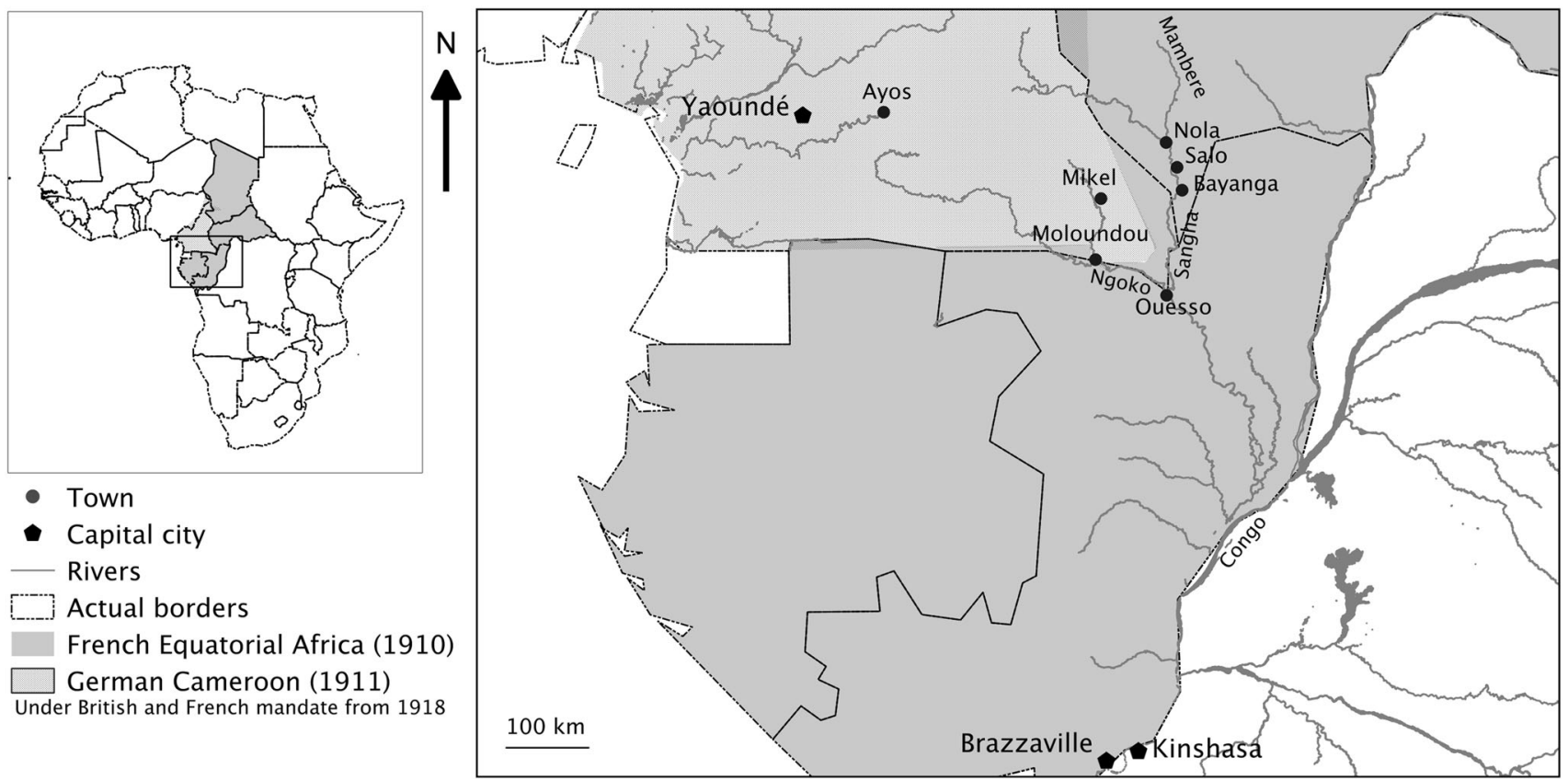

Figure 1. The Sangha basin of equatorial Africa.

Second, historical analyses of the nineteenth century Sangha basin reveal mobility, vibrant economic activity, and ample access to firearms for some societies (Siroto 1969; Harms 1981; Copet-Rougier 1998; Guillaume 2001; Giles-Vernick 2002; Klieman 2003; Rupp 2011). Pressures on nineteenth century forest populations came from the north, south, and west, precipitating intensive warfare, flight, slave raiding, and trade in food crops and forest products for medical treatment and bodily adornment (Loyre 1909; Cottes 1911; Copet-Rougier 1998). Sangha basin riverine and forest-edge societies actively traded guns, local slaves, ivory, foods, and other commodities (Siroto 1969; Harms 1981, 1987; Copet-Rougier 1980, 1998; Klieman 2003). Forest societies, such as the Bangando, engaged in local, regional, and long-distance trade; iron (injewuso) and brass currencies and a prized powder made from red hardwood (mongwélé) for bodily adornment circulated.

For some researchers and commentators, HIV emergence offers a model for newly emerging diseases from the African equatorial rain forest (Wolfe et al. 2005, 2007; Wolfe 2011; Pepin 2011; Quammen 2012, 2015). Ecological and historical evidence indicates that although hunting and butchering could be the source of SIVcpz infection in human beings, other human-chimpanzee interactions may also have provided opportunities for transmission. Ethnoprimatologist Agustín Fuentes argues that people and NHPs "are simultaneously actors and participants in sharing and shaping mutual ecologies... an interweaving of structural and social ecologies" (Fuentes 2010). The full range of interactions in these interwoven ecologies may be central to understanding HIV and other emerging diseases. Training our sights exclusively on hunting and butchering neglects the "mutual ecologies" and other activities potentially facilitating chimpanzee-to-human transmission.

\section{MetHOdS}

Southeastern Cameroon, bordered by the Sangha and Ngoko rivers, has long been a linguistic, socio-cultural, economic, and political crossroads. Understanding its place in HIV's historical emergence requires deep knowledge of its history and social, ecological, and economic connections with the Sangha basin forest. We base the present analysis on 4 months of oral historical field research and participant-observation of daily activities in southeastern Cameroon during 2015-2016, investigation of colonial administrative and missionary archives, and long-term historical and anthropological research experience in southeastern Cameroon (Rupp and Ambata) and in the middle Sangha basin forest (Giles-Vernick).

Using an interview guide pretested in 2014, we conducted 62 semi-structured, oral historical interviews on hunting, butchering, gathering, illness and treatment, ri- 
tual, mobility, ecological use and change, and trade and economic change. We used snowball sampling to identify and interview 14 women and 53 men over 50 years old and knowledgeable about the past. Interviews were conducted and recorded in Bangando, Baka, and French. We also recorded proverbs and tales from four women and seven men. All recordings were transcribed verbatim by an assistant. Rupp verified transcriptions and translations into French.

We conducted participant-observation of men's and women's activities that bring them into contact with NHPs, taking detailed notes of these observations.

Finally, we conducted archival research at the Centre des Archives d'outre-mer (Aix-en-Provence) and at various libraries in France: relevant missionary archives (Chevillyla-rue and Annecy, France), the Bundesarchiv (German colonial archives), the papers of French anthropologist Elisabeth Copet-Rougier concerning late pre-colonial and early colonial years in the Sangha basin.

We used nested scales of analysis to evaluate HIV beginnings. Our present field research focused on Bangando, Baka, and Bakwélé individuals living in villages from Mikel to Moloundou in the Lobéké forest of southeastern Cameroon. We also based our analysis on previous historical and anthropological research, as long-term, intensive agricultural, trading, and cultural and political exchanges linked communities in southeastern Cameroon with those of the middle Sangha basin.

The Cameroonian National Research Ethics Committee and Institut Pasteur Institutional Review Board gave ethical approvals for the study. All informants provided informed consent.

We used qualitative content and discourse analysis for all data (Forman and Damschroder 2008). After reading all transcriptions, archival documents, and notes, we conducted line-by-line, inductive and deductive coding, and then revised our codes to account for larger data segments. We evaluated results generated by these coding exercises and wrote memos to analyze relationships between our data, codes, and analytical categories. From these analyses, we developed a historical explanation of HIV emergence based on colonial and missionary data, oral histories, and published phylogenetic analyses.

Several strategies ensured rigorous data collection and analysis. We remained attentive to the different historical and social perspectives from which our data were produced, and triangulated oral histories with colonial documents, published historical accounts, and biomedical literatures on HIV. We presented our study results at five international conferences of HIV and emerging disease specialists (Rupp 2014; Giles-Vernick 2014; Giles-Vernick 2015; Rupp 2015; Giles-Vernick 2016; Rupp 2016).

\section{Results}

Our oral historical and archival research shows that the imposition of colonial rule was an uneven process spanning nearly three decades. After 1920, colonial rule intensified transformations that augmented the frequency of contact with chimpanzees and likely adapted the infection for human sexual transmission (Table 1).

\section{Human-Chimpanzee Contact Through Ecological and Economic Transformations}

Even before effective colonization, European commercial networks had begun to transform human, chimpanzee, and ecological relations in the Sangha basin region. By 1891, Belgian and Dutch trading companies purchased rubber and ivory along the Sangha and Ngoko rivers and exported these products via steamer; Hausa and Fulbé caravans purchased and transported ivory northwards (Gaillard 1891; Mittler 1898; Anonymous 1899).

Following initial German explorations of southeastern Cameroon in 1897, the first wave of colonial control and intervention came in the form of concessionary companies. The Gesellschaft Südkamerun (GSK), based in Hamburg, Germany, was established in 1898 as a private trading company paying yearly rents (10\% share of profits) in exchange for access to resources and laborers in a vast concession of 81,597 square kilometers in southeastern Cameroon. The company controlled the German colonial outpost in Moloundou, developing a rubber depot, warehouses, and a port connecting steamer traffic along the Sangha and Congo rivers (Fourneau 1900; Cureau 1911). GSK operated until 1915, when France forced Germany's withdrawal from the Sangha region. After imposing de facto control over what would become French Cameroon in 1916, France continued to impose its concessionary system throughout the middle and upper Sangha basin forests until the 1920s (CoqueryVidrovitch 1972). Environmental exploitation and agricultural production continued and intensified under other private commercial enterprises from the 1920s to 1960.

The colonial regimes introduced new forms of environmental extraction and reoriented benefits to accrue to 
Table 1. Summary of Major Historical Developments and Their Dates of Intensification

\begin{tabular}{|c|c|}
\hline Event & Dates of intensification after the imposition of colonial rule \\
\hline Elephant hunting & $1890 \mathrm{~s}$ \\
\hline Other mammal hunting (including NHPs) & After 1920 \\
\hline \multirow[t]{3}{*}{ Gun possession } & Uneven \\
\hline & Some riverine societies possessed from mid-nineteenth century; \\
\hline & Other forest societies acquired only after 1920 \\
\hline \multirow[t]{4}{*}{ Nonhuman primate domestication } & Disputed \\
\hline & Some oral histories support domestication well before colonialism \\
\hline & Some oral histories identify domestication as colonial practice \\
\hline & Archival evidence after 1920 \\
\hline \multirow[t]{3}{*}{ Rubber collection } & $1907-12$ \\
\hline & $1915-20$ \\
\hline & $1925-26$ \\
\hline Agricultural expansion & After 1920 \\
\hline \multirow[t]{2}{*}{ Labor recruitment } & Limited 1900-1914 \\
\hline & Intensified after 1920 with commercial plantations and railway construction \\
\hline \multirow[t]{2}{*}{ Riverine transport } & Ongoing in nineteenth century \\
\hline & Irregular and difficult into $1930 \mathrm{~s}$ \\
\hline Road transport & After 1920 \\
\hline Routine health care & After 1920 \\
\hline Medical campaigns (sleeping sickness) & Before 1920, interventions concentrated in the Centre region, Cameroon \\
\hline
\end{tabular}

More likely contributions to intensified and more frequent contact between people and chimpanzees are italicized.

companies and colonial powers through rents. They propelled African subjects into new or expanded activities that could enhance cross-species transmission possibilities and adapt HIV to human-to-human transmission.

\section{Hunting and Gun Access}

Equatorial Africans had long hunted animals, including chimpanzees, gorillas, elephants, and other species. Forest groups, including Bangando, Baka, and Bakwélé, hunted elephants for meat, which entered into networks of exchange for ordinary and ritual consumption. In the nineteenth century, ivory was a marker of political power and social prestige, but was neither hoarded nor traded for economic gain. Under colonial rule, hunting practices and motivations changed, and offtake accelerated after 1920.

Archival sources, explorers' accounts, and oral histories attest to changing relations with forest animals after 1900. These changes occurred in two phases. In the first, European trading companies and subsequently GSK increased elephant hunting for ivory (Gaillard 1891; Mittler 1898; Stoecker 1986). We found no evidence, however, of expanded hunting of other animals until the 1920s. One aged woman who had witnessed the arrival of the French after the German retreat recounted, "There was a change during the French period. Fear was finished. Everybody was looking for meat, and these animals (chimpanzees) were meat. We could also sell the young. So everyone hunted them."

For Africans not already possessing firearms, access to guns did not come immediately with colonial rule's imposition. Interviewed elders differed about when and how they gained access to guns. Some insisted that their ancestors obtained guns before colonization. Others indicated that although they previously hunted with crossbows and spears, certain villages during German colonization might have acquired one gun for a chief or elder, but that arms acquisitions expanded under the French before the Second World War.

Uprisings in French Congo and German Kamerun in the early twentieth century led colonial authorities to restrict African subjects' gun access before the First World War (Pauwels 1901; Mestayer 1902; Loyre 1909; Stoecker 1986). Before and during the war, many guns were imported, mostly destined for colonial troops and European administrators and agents. Although certain concessionary 
companies smuggled arms and bullets to pay African subjects (Coquery-Vidrovitch 1972), our informants' accounts and archival sources indicate that this did not happen in the Lobéké or middle Sangha region. Concessionary company reports in the century's second decade observed that African hunters used spears and large traps, or re-outfitted guns to shoot spears (Gouvernement Général de l'Afrique Equatoriale Française 1913; Douet 1914; Gouvernement Général de l'Afrique Equatoriale Française 1917).

\section{Nonhuman Primate Domestication}

Domestication and trade of NHPs was another potential source of human-chimpanzee contact. Elders recounted that offspring of hunted chimpanzees and gorillas were sold to French colonial administrators and company agents, who dressed them up to amuse family and friends, serve guests, and work as domestic help. Although we cannot date the earliest NHP domestications or markets, we know this practice existed by the late 1920s. In 1928, the Compagnie Forestière de la Sangha-Oubangui published new tariffs for river transport from Ouesso along the Sangha and N'Goko rivers, charging five francs for carrying "parrots, monkeys and dogs" (Direction Comptoir Ouesso 1928; Gondran 1928). Steamer transport of NHPs was frequent enough to merit mention on transport price lists. No archival evidence documents NHPs traveling from Ouesso and Brazzaville, but Lobéké elders asserted that "everything" saleable traveled on those steamships, including chimpanzees. One elder described different baskets that her mother fabricated for transporting live monkeys, chimpanzees, and young gorillas on steamships.

\section{Rubber and Other Gathered Products}

Commercial interests introduced rubber collection before the arrival of German colonial and concessionary administrators. Overall, production expanded between 1907-1912 (Anonymous 1912), thereafter interrupted by a global rubber market crisis and the First World War. It revived in 1915-1920, 1925-26, and finally during the Second World War (Coquery-Vidrovitch 1972; Austen and Headrick 1983). Although some researchers suggested that rubber collection expanded chimpanzee hunting (Chitnis et al. 2000), we found no archival or oral evidence of increased chimpanzee hunting until after 1920.

Sangha basin oral histories attest to hunger and exhaustion from forced rubber collection, preparation, and porterage. Unsurprisingly, medical surveys documented many infectious diseases and skin disorders among Sangha basin populations, who sought medical treatment in Moloundou, Ouesso, or Nola (Headrick 1994).

Other forest products escaped colonial observers' sights, but have long been important in local diets throughout equatorial Africa (Klieman 2003). In the Lobéké region, people gather wild mangoes (Irvingia spp.) seasonally, extracting the endosperm, which they dry, grill, and pound to make sauces. Chimpanzees, gorillas, and other NHPs also favor these fruits, making wild mango collection sites places of human-NHP contact and competition. Many informants acknowledged that if people found partly eaten fruit left behind by chimpanzees and gorillas, some would eat the remaining fruit, and others would handle it to extract the endosperm.

\section{Agricultural Expansion}

Although agricultural production stagnated with initial colonization, demand for and production of cultivated products and foodstuffs expanded from the 1920s (Landrau 1945; Coquery-Vidrovitch 1972). Coquery-Vidrovitch attributes this expansion to the concessionary system's demise and the creation of new commercial enterprises, the development of a salaried worker class and markets, and the imposition of coerced labor. Oral histories collected throughout the middle Sangha confirm this expanding agricultural production from the 1920s.

Colonial observers observed NHP crop raiding throughout the middle Sangha from the late 1920s (Trechot 1931; Saint-Félix 1932; Sintas 1944). Contemporary studies show that expanding agricultural spaces attract NHP crop raiding, which can facilitate pathogen-sharing through aggression and shared foods (Fuentes and Hockings 2010). Our informants described substantial dry season crop raiding in banana gardens and cocoa stands, with one cultivator observing, "When apes enter a garden, it's a massacre."

\section{Reoriented Mobilities}

Over three decades, colonial rule ushered in new mobility patterns through the use of colonial troops to establish order, and through labor recruitment and the development of riverine transport and roads. These changes led to new forms of sociality, expanding both the populations to whom HIV could be transmitted and the directions of pathogenic dissemination. 
German colonial rule brought new people into the region-company agents, a small number of mercenaries, and many laborers from neighboring French and Belgian colonies (Geisler 1909; Neill 2012). In their brief rule, Germans forcibly conscripted African subjects to collect wild rubber from the Lobéké forests and haul it to Moloundou, according to elders' bitter recollections.

Marked changes came by the 1920s with the consolidation of French rule and the arrival of administrators, company agents, and troops from France and West Africa. The creation of a formal labor recruitment system and commercial agriculture and exploitation drew laborers in multiple directions: to oil palm stands near Ouesso, across the river to coffee and cacao plantations in Nola, Bayanga, and Salo, to the Congo-Océan railway construction sites in the late 1920s, and Gabon forestry companies (Association du Commerce 1925; Recrutement Consortium Forestière 1930; Gondran 1929; Anonymous 1942). Numerous elders recounted movements of workers, troops, and wives in all directions to and from the Lobéké forest.

Riverine and road networks also developed, but at different times and with different capacities. Riverboat transport along the Sangha River and its tributaries evacuated commodities and moved workers, troops, and administrators to Kinshasa and Brazzaville, from Moloundou eastward to Ouesso, and northward on the Sangha and Mambéré rivers. Following the First World War, the behemoth Compagnie Forestière de la SanghaOubangui and Nola trading houses expanded their extractive and trading activities into Cameroon, reorienting products and people through contiguous trade and administrative nodes in Ubangi-Shari (Nola, Salo, Bayanga). Sangha River transport was irregular and difficult, impeded by a changing seasonal ecology, high costs, and frequent breakdowns (Ponel 1896; Plehn 1899; Bruel 1909; Gouvernement Général de l'A.E.F. 1911; Anonymous 1919; Devouton 1935). Road building accelerated from the 1920s.

\section{Medical Campaigns and Routine Care}

Superimposed upon these reoriented political ecologies and mobilities were new, invasive medical practices. Serial passage-the sequential transmission of infected blood from one person to another-resulting from injection campaigns appears to be the means by which SIV adapted to human transmission (Marx et al. 2001; Sharp and Hahn 2011).

Clinics and hospitals using poorly sterilized instruments and syringes may have contributed to this process.
German colonizers constructed a health clinic in Moloundou by 1909. Ouesso and Nola had rudimentary hospitals by then (Conan 1913). Injections, sutures, and minor surgeries were part of daily medical care, although blood transfusion was not introduced into French Congo until 1933 (Headrick 1994; Grmek 1990; Schneider 2013). French colonial health activities and interventions expanded in Cameroon, Moyen-Congo, and Ubangi-Shari from the 1920s (Brau 1925; Headrick 1994).

Sleeping sickness campaigns have been suggested as a means of amplifying HIV-1M transmission through unsterilized needles to extract blood and lymph samples or to inject atoxyl or other treatments (Pepin et al. 2010; Iliffe 2006). In the Lobéké forest, ecological conditions did not favor trypanosome-carrying tsetse as they did further north (Ouzilleau 1911; Brau 1925), and local populations resisted German attempts to conduct screening (Geisler 1909, quoted in Neill 2012). Sleeping sickness control was concentrated further west (Brau 1925; Jamot 1932; Millous 1936; Tantchou 2007; Neill 2012; Lachenal et al. 2016).

\section{Discussion}

Not all SIV transmission can be explained through primate hunting and blood contact, and thus we explore multiple historical activities and processes facilitating humanchimpanzee contact and their timing to gain insight into early HIV-1M emergence. Contacts between people and chimpanzees were multiple in the early twentieth century. Several interacting practices and historical processes may have permitted initial SIV transmission to people and enhanced HIV-1Ms adaptation after 1920.

Hunting and butchering chimpanzees constitute one high-risk practice, but Middle Sangha basin inhabitants had long hunted chimps, with and without firearms. Multiple African groups acquired firearms from the 1850s, before colonial rule. Moreover, gun possession did not abruptly escalate with colonization, but increased incrementally in the Lobéke region until the 1920s. Although the index patient of HIV-1M may have been an African male hunter, other people-colonial soldiers, European administrators, company agents—had greater access to firearms and could also have been the index patient.

Other activities facilitated human-chimpanzee contacts. Agriculture declined after initial colonization, but expanded from the 1920s and likely attracted crop raiding by chimpanzees. It merits closer attention as a practice 
potentially facilitating SIV transmission to human beings. Gathering, too, should be considered as a potential source of contact and pathogen-sharing. Finally, colonial domestication of chimpanzees was another transmission pathway to people, either in the Sangha basin, or possibly in Brazzaville-Kinshasa, if an infected captive chimpanzee traveled there.

Rubber collection under German rule seems neither to have increased chimpanzee hunting nor exposure to trypanosome-carrying tsetse flies. Nevertheless, from the 1920s, forced labor-rubber collecting, portaging, road building, expanded agricultural production-taxed people's bodies, sapped their productive abilities, and likely transformed animal and disease ecologies. Physical depletions may have rendered people more vulnerable to sickness. Some sought physical relief in regional medical clinics and hospitals. Others pursued new livelihood and employment opportunities in the wider Sangha basin, including Ouesso and Nola, Gabon, and Brazzaville-Kinshasa.

Such changes contributed to HIV-1M's adaptation and spread. Changing mobility patterns were an important response to physical duress, but not necessarily by the direct path of a "cut hunter" to Brazzaville-Kinshasa. Our evidence points to significant, durable changes in mobility after 1920, which propelled workers south to these growing cities, and also to commercial enterprises north, south, and east of this region. New mobility patterns created new marital alliances with mobile military troops and laborers, expanding the directions of pathogenic dissemination and populations to whom HIV could potentially be transmitted.

Finally, our historical evidence suggests that medical interventions could have facilitated HIV adaptation to human transmission through medical campaigns and routine care after 1920. Clinics and hospitals offered care that could have facilitated adaptation through serial passage, while mass medical campaigns-for example in Nola-could have adapted or amplified HIV-1M, setting the foundations for a pandemic-in-the-making.

\section{CONCLUSION}

This exercise offers more historically grounded insight into early HIV emergence than the "cut hunter" hypothesis. Historical sources illuminate the changes precipitated over three decades of colonial rule, and specifically their influ- ence on cross-species SIVcpz transmission to human beings and HIV adaptation to human beings. Contact with chimpanzees came through many activities-hunting and butchering, chimpanzee domestication, agricultural expansion, and gathering. After the 1920s, colonial rule intensified human mobility and exposure to invasive medical practices, facilitating the adaptation of a simian virus to human transmission. We narrow the time frame of emergence to years after 1920, a period described as "the beginnings of a profound transformation in economic conditions...that translated into a deterioration in the fates of the populations, engendered serious revolts, and resulted in dramatic poverty" (Coquery-Vidrovitch 1972). Historical evidence does not permit a definitive identification of the Patient Zero of the HIV pandemic, but should encourage us to discard the historically flawed proposition of the cut hunter. Empirically based investigations bring other drivers of new disease emergence into clearer focus.

\section{ACKNOWLEDGMENTS}

We thank the people of the Lobéké forest for generously sharing their recollections of the past. We are also grateful to Deborah Neill for her guidance and insights into the early sleeping sickness epidemic in the middle Sangha basin.

\section{FUNDING}

This study was funded by the National Endowment for the Humanities (Collaborative research Grant No. RZ-5152313) and the Agence Nationale de la Recherche (France) (Grant No. ANR-14-CE31-0004-02).

\section{REFERENCES}

Anonymous (1899) Nouvelle station Sangha-Ngoko. Deutsches Kolonialblatt. Fonds Elisabeth Copet-Rougier, Laboratoire d'anthropologie sociale, Collège de France, Travail sur des archives des colonies en Afrique, Archives allemandes, FEC.B.S1.01.04.001

Anonymous (1912) Deutsches Kolonialblatt, 23:498.

Anonymous (1919) Territoires Occupés Militairement du Nouveau Cameroun. Circonscription de la Kadéi-Sangha, Rapport Général, sur la Société Forestière Sangha Oubangui, pour l'année 1919, Centre des archives d'outre-mer (hereafter CAOM), 8Q 31 (Compagnie Forestière de la Sangha Oubangui, Rapports généraux administratifs sur la compagnie, Ouesso subdivision). 
Anonymous (1942) Note pour Monsieur le Chef de cabinet de M le Secrétaire Général, CAOM, 2H19 (Recrutement 1945-1947)

Association du Commerce, à Monsieur le Gouverneur Général de l'Afrique Equatoriale Française, Port-Gentil le 15 Déc 1925, CAOM, 2H16 (Recrutement des travailleurs indigènes pour des entreprises privées, arrêtés, correspondances, 1925-35)

Austen R, Headrick R (1983) Equatorial Africa under colonial rule. In: History of Central Africa, Birmingham D, Martin P (editors), London: Longman, pp 27-94

Bibollet-Ruche F, Galat-Luong A, Cuny G, Sarni-Manchado P, Galat G, Durand JP, Pourrut X, Veas F (1996) Simian immunodeficiency virus infection in a patas monkey (Erythrocebus patas): evidence for cross-species transmission from African green monkeys (Cercopithecus aethiops sabaeus). in the wild. Journal of General Virology 77:773-781

Brau (1925) La lutte contre la maladie de sommeil. Histoire de la lutte. Annales d'hygiène et de médecine coloniales 23:405-444

Bruel G (1909) Les basses vallées de l'Oubangui et de la Sangha La Géographie. Bulletin de la Société de Géographie 19:353-366

Chitnis A, Rawls D, Moore J (2000) Origin of HIV type 1 in colonial French Equatorial Africa? AIDS Research and Human Retroviruses 16:5-8

Conan (1913) Organisation du Service de Santé en Afrique Equatoriale Française. Annales d'Hygiène Coloniale 16:1-73

Copet-Rougier E (1980) Carnets de terrain, 1980, tome III. Fonds Elisabeth Copet-Rougier, Laboratoire d'anthropologie sociale, Collège de France, FEC B.53.01.02.001

Copet-Rougier E (1998) Political-economic history of the Upper Sangha. In: Resource Use in the Trinational Sangha River Region of Equatorial Africa: Histories, Knowledge Forms, and Institutions, bulletin series Yale University School of Forestry and Environmental Studies, no. 102, Eves HE, Hardin R, Rupp S (editors), pp $41-84$

Coquery-Vidrovitch C (1972) Le Congo Au Temps Des Compagnies Concessionnaires 1898-1930, Paris: Mouton

Cottes A (1911) La Mission Cottes Au Sud Cameroun (1905-1908), Paris: Ernest Leroux

Cureau AD (1911) Rapport sur le Tracé de la Frontière entre le Congo Français et le Cameroun (Région Sangha-N'Goko. In: Cottes Au Sud-Cameroun, Mission La (editor), Paris: Ernest Leroux, pp 1905-1908

De Souza JD, Müeller V, Lemey P, Vandamme A-M (2010) High GUD incidence in the early 20th century created a particularly permissive time window for the origin and initial spread of epidemic HIV strains. PLoS One 5(4):e9936

Devouton (1935) Rapport fait par M DEVOUTON, Inspecteur de $2^{\text {ème }}$ classe des Colonies, concernant les travaux d'équipement du réseau fluvial Congo-Oubangui-Sangha et l'exploitation des moyens de transport sur ces fleuves, CAOM, Fonds Ministériels, 1TP369 (Travaux publiques, Inspections des Colonies. Colonie de l'A.E.F. Mission 1934-35).

Direction Comptoir Ouesso, CFSO (1928) Tarifs des transports fluviaux, CAOM, AEF 8Q29 (Compagnie Forestière de la Sanga Oubangui)

Douet ML (1914) Les Babingas ou Yadingas. L'Ethnographie (nouvelle série) 2:15-30

Faria NR, Rambaut A, Suchard MA, Baele G, Bedford T, Ward MJ, Tatem AJ, Sousa de JD, Arinaminpathy N, Pépin J, Posada D, Peeters M, Pybus OG, Lemey P (2014) The early spread and epidemic ignition of HIV-1 in human populations. Science 346:56-61
Forman J, Damschroder L (2008) Qualitative content analysis. In: Jacoby L, Siminoff LA (editors) Empirical methods for bioethics: a primer. Advances in Bioethics 11:39-62

Fourneau L (1900) Mission Fourneau, Rapport Anecdotique. Revue Coloniale 6:1341-1370

Fuentes A (2010) Naturalcultural encounters in Bali: monkeys, temples, tourists and ethnoprimatology. Cultural Anthropology 25:600-624. doi:10.1111/j-1538-1360.2010.01071.x

Fuentes A, Hockings KJ (2010) The ethnoprimatological approach in primatology. American Journal of Primatology 72:841-847

Gaillard (1891) Rapport de M. l'Administrateur Gaillard, sur son voyage dans la Sangha. CAOM Mission 24

Geisler (1909) Bericht betr. Schlafkrankheit gem. Vfg. d.Gouv v. 24.V.09 J No. 6568/08. Molundu, Aug 24, Bundesarchiv BerlinLichterfelde (hereafter BArch) R1001 Bl. 153-156

Giles-Vernick T (2002) Cutting The Vines Of The Past: Environmental Histories of The Central African Rain Forest, Charlottesville: University of Virginia Press

Giles-Vernick, T (2016) Rethinking early emergence of HIV-1M in central Africa: Why we need to consider the 19th c. Sangha Basin. Presented at the conference Histories of HIVs: Social contexts of the emergence of HIV/AIDS, American Museum of Natural History, New York City.

Giles-Vernick, T (2015) Against the cut hunter: An historical evaluation of HIV beginnings in equatorial Africa. Presented at the conference, understanding human-animal disease: emergency, ecologies, ethnography, Durham University, Durham, UK.

Giles-Vernick, T (2014) Pathogenic exchanges, people and great apes in the Congo and Sangha river basins of equatorial forest. 113th annual meeting of American Anthropological Association, Washington, DC.

Gondran (1928) L'administrateur des Colonies Gondran, Chef de la Circonscription de la N'Goko Sangha à Monsieur le Gouverneur Général de l'Afrique Equatorial Française (FinancesMoyen Congo) à Brazzaville. No 50, Transports fluviaux sur réquisitions, CAOM AEF 8Q29 (Compagnie Forestière de la Sanga-Oubangui)

Gondran (1929) L'administrateur des Colonies Gondran, Chef de la Circonscription de la N'Goko -Sangha to Monsieur le Gouverneur Général de l'Afrique Equatoriale Française (Main d'œuvre), No 111, CAOM AEF, 3H30-32 (Recrutement)

Gouvernement Général de l'Afrique Equatoriale Française, Colonie du Moyen Congo (1913) Rapport Général sur la Société Forestière de la Sangha Oubangui (Secteurs Ekela-N'Daki) pour l'année 1912, CAOM 8Q30 (CFSO)

Gouvernement Général du Congo Français, Colonie du Moyen Congo (1911) Rapport Général sur la Compagnie Forestière de la Sangha Oubangui, Secteur Carnot, CAOM 8Q30 (CFSO)

Gouvernement Général du l'Afrique Equatoriale Française, Colonie du Nouveau Cameroun (1917) Rapport Géneral sur la Compagnie Forestière de la Sangha Oubangui, CAOM 8Q31 (CFSO)

Grmek MD (1990) History Of AIDS: Emergence And Origin Of A Modern Pandemic, Princeton: Princeton University Press

Guillaume H (2001) Du miel au café, de l'ivoire à l'acajou. La colonisation de l'interfleuve et l'évolution des rapports entre chasseurs-collecteurs pygmées Aka et agriculteurs (Centrafrique-Congo), 1880-1980, Paris: Edition Peeters/SELAF.

Hahn BH, Shaw GM, de Cock K, Sharp PM (2000) AIDS as zoonosis: scientific and public health implications. Science 287:607-614 
Harms R (1981) River Of Wealth, River Of Sorrow: The Central Zaire Basin In The Era Of The Slave And Ivory Trade, 1500-1891, New Haven: Yale University Press

Harms R (1987) Games Against Nature: An Eco-Cultural History Of The Nunu Of Equatorial Africa, Cambridge: Cambridge University Press

Headrick R (1994) Colonialism, health and illness in French Equatorial Africa, 1885-1935, Headrick D (editor), Atlanta: African Studies Association

Hofreiter M, Kreuz E, Eriksson J, Schubert G, Hohmann G (2010) Vertebrate DNA in fecal samples from Bonobos and Gorillas: evidence for meat consumption or artefact? PLoS One 5:e9419. doi:10.1371/journal.pone.0009419

Holl A (1991) Cameroun. In: Aux Origines de l'Afrique Centrale, Lanfranchi R, Clist B (editors) Libreville, Gabon: Centre Culturel Français, pp 149-154, 192-196.

Iliffe J (2006) The African AIDS Epidemic: A History, Athens: Ohio University Press

Jamot (1932) La lutte contre la maladie du sommeil au Cameroun. Annales de l'Institut Pasteur 48:490-502

Johnson CK, Hitchens PL, Evans TS, Goldstein T, Thomas K, Clements A. Joly DP, Wolfe ND, Daszak P, Karesh WB, Mazet JK (2015) Spillover and pandemic properties of zoonotic viruses with high host plasticity. Scientific Reports 5/14830. DOI:10. 1038/srep14830

Keele BF, Van Heuverswyn F, Li Y, Bailes E, Takehisa J, Santiago ML, Bibollet-Ruche F, Chen Y, Wain LV, Liegeois F, Loul S, Ngole EM, Bienvenue Y, Delaporte E, Brookfield JFY, Sharp PM, Shaw GM, Peeters M, Hahn BH (2006) Chimp reservoirs of pandemic and nonpandemic HIV-1. Science 313:523-526. doi:10.11266/science.1126531

Klieman K (2003) "The Pygmies Were Our Compass": Bantu and Batwa In The History of West Central Africa Early Times to $c$. 1900 C.E, Heinemann: Greenwood Pub Group

Lachenal G, Owona Ntsama J, Ze Bekolo D, Kombang Ekodogo T, Manton J (2016) Neglected actors in neglected tropical diseases research: historical perspectives on health workers and contemporary Buruli ulcer research in Ayos, Cameroon. PLoS NTD 10:e004488. doi:10.1371/journal

Landrau H (1945) Instructions sur l'utilisation de la main d'œuvre indigène et sa répartition en A.E.F., CAOM $2 \mathrm{H} 13$ (Recrutement et relève de travailleurs, principes, conditions de recrutement et de rapatriement des travailleurs indigènes: arrêtes, correspondance, etc. 1905-1946)

Locatelli S, Peeters M (2012) Cross-species transmission of simian retroviruses: how and why they could lead to the emergences of new diseases in the human population. AIDS 26:659-673. doi:10.1097/QAD.0b013e328350fb68

Loyre E (1909) Les populations de la Moyenne Sanga. Questions diplomatiques et coloniales 28:406-420

Marx PA, Alcabes PG, Drucker E (2001) Serial human passage of simian immunodeficiency virus by unsterile injections and the emergence of epidemic human immunodeficiency virus in Africa. Philosophical Transactions of the Royal Society of London Series B 356:911-920

Mestayer, G (1902) L'Administrateur Délégué à Monsieur le Ministre des Colonies (Decrais) CAOM, Gabon Congo III, dossier 13

Millous (1936) Le traitement de la maladie du sommeil au Cameroun. Annales de médecine et de pharmacie coloniales 34:966-995
Mittler BES (1898). Deutsches Kolonialblatt. Umtsblatt für die Schutzgebiete des Deutschen Reichs. IX. Jahrgang, 1898. Berlin . Kamerun. Expedition v. Carnap. 272-274. Fonds Elisabeth Copet-Rougier, Laboratoire d'anthropologie sociale, Collège de France, Travail sur des archives des colonies en Afrique, Archives allemandes, FEC.B.S1.01.04.001.

Mossoun A, Pauly M, Akoua-Koffi C, Couacy-Hymann E, Leendertz SA, Anoh AE, Gnoukpoho AH, Leendertz FH, Schubert G (2015) Contact to non-human primates and risk factors for zoonotic disease emergence in the Taï Region, Côte d'Ivoire. EcoHealth 12:580-591. doi:10.1007/s10393-015-1056-x

Neill D (2012) Networks In Tropical Medicine: Internationalism, Colonialism And The Rise of A Medical Specialty, Stanford: Stanford University Press

Ouzilleau F (1911) La maladie du sommeil dans la Haute Sangha. Annales d'hygiène et de médecine coloniale 14:332-352

Paige SB, Frost SDW, Gibson MA, Jones JH, Shankar A, Switzer WM, Ting N, Goldberg TL (2014) Beyond bushmeat: animal contact, injury, and zoonotic disease risk in western Uganda. EcoHealth 11:534-543. doi:10.1007/s10393-014-0942-y

Pauwels (1901) M. Pauwels à M. l'Administrateur Délégué C.P.S. Paris, CAOM, Gabon-Congo III, dossier 13

Peeters M, D'Arc M, Delaporte E (2014) The origin and diversity of human retroviruses. AIDS Review 16:23-34

Pepin J (2011) The Origins of AIDS, Cambridge: Cambridge University Press

Pepin J, Labbé AC, Mamadou-Yaya F, Mbélesso P, Mbandingai S, Deslandes S, Locas MC, Frost E (2010) Iatrogenic transmission of human retrovirus HTLV-1 and of Hepatitis C virus through parenteral treatment and chemoprophylaxis of sleeping sickness in colonial Equatorial Africa. Clinical Infectious Diseases 51: $777-784$

Plehn (1899) Nouvelle station de Sangha-Ngoko. In: Deutsch Kolonialblatt. Umtsblatt für die Schutzgebiete des Deutschen Reichs. Kamerun. Expedition v. Carnap. Fonds Elisabeth CopetRougier, Laboratoire d'anthropologie sociale, Collège de France, Travail sur des archives des colonies en Afrique, Archives allemandes, FEC.B.S1.01.04.001

Ponel E (1896) La Haute Sangha (Congo Français). Bulletin de la Société de Géographie de Paris 7:188-211

Quammen D (2012) Spillover: Animal Infections And The Next Human Pandemic, New York: WW Norton \& Company

Quammen D (2015) The Chimp And The River: How Aids Emerged From The African Forest, New York: WW Norton \& Company

Recrutement Consortium Forestière (1930) Le Gouverneur Général de l'Afrique Equatoriale Française commandeur de la Légion d'Honneur Chargé de l'Administration du Moyen-Congo à Monsieur le Chef de la Circonscription de la Haute-Sangha (Carnot). CAOM, AEF 2H16 (Recrutement des travailleurs indigènes pour des entreprises privées, arrêtés, correspondances, 1925-35).

Rupp S (2011) Forests Of Belonging: Identities, Ethnicities, And Stereotypes In The Congo River Basin, Seattle: University of Washington Press

Rupp, S (2016) Social and historical contexts of HIV-1 emergence in Southeastern Cameroon. Presented at the Conference Histories of HIVs: Social contexts of the emergence of HIV/AIDS, American Museum of Natural History, New York City.

Rupp S (2015) Historical and social contexts of HIV-1M Emergence: Evidence from Southeastern Cameroon. 64th annual meeting of American Society for Tropical Medicine and Hygiene annual meeting, Philadelphia. 
Rupp S (2014) People and primates: investigating interspecies intimacies in the history of HIV/AIDS Emergence. 57th Annual meeting of African Studies Association Annual Meeting, Indianapolis.

Saint-Félix (1932) à M le Gouverneur Général de l'Afrique Equatoriale Française (Direction des Affaires Politiques), CAOM 8Q14 (Divers)

Schneider WS (2013) The History Of Blood Transfusion In SubSaharan Africa, Athens: Ohio University Press

Sharp PM, Hahn B (2011) Origins of HIV and the AIDS pandemic. Cold Spring Harb Perspect Med 1:a006841

Sintas PA (1944) Extraits du Rapport de Visite Pastorale de Mgr Sintas en pays Mbimou du 8 au 16 octobre 1944. Archives des Capucins de Toulouse, 4R.

Siroto L (1969) Masks and social organization among the Bakwele people of western equatorial Africa. $\mathrm{PhD}$ dissertation, Columbia University.

Stoecker H (1986) German Imperialism In Africa From The Beginnings Until The Second World War, London: C. Hurst \& Company

Takehisa J, Kraus MH, Ayouba A, Bailes E, Heuverswyn Van, Decker JM, Li Y, Rudicell RS, Learn GH, Neel C, Ngole EM, Shaw GM, Peeters M, Sharp PM, Hahn BH (2009) Origin and biology of simian immunodeficiency virus in wild-living western gorillas. Journal of Virology 83:1635-1648. doi:10.1128/JVI.02311-08

Tantchou J (2007) Epidémie et Politique En Afrique, Maladie Du Sommeil Et Tuberculose, Paris: L'Harmattan

Trechot H (1931) Trechot (Compagnie Française du Haut et Bas Congo) à M le Gouverneur Général, CAOM 8Q14 (Divers)
Van Heuverswyn F, Li Y, Neel C, Keele BF, Liu W, Loul S, Butel C, Liegeois F, Bienvenue Y, Ngolle EM, Sharp PM, Shaw GM, Delaporte E, Hahn BH, Peeters M (2006) Human immunodeficiency viruses: SIV infection in wild gorillas. Nature 444:164

Vansina J (1990) Paths In The Rainforests: Toward A History Of Political Tradition In Equatorial Africa, Madison: University of Wisconsin Press

Webb JLA Jr (2013) Historical epidemiology and infectious disease processes in Africa. Journal of African History 54:3-10

Wolfe ND (2011) The Viral Storm: The Dawn Of A New Pandemic Age, New York: Times Books

Wolfe ND, Dunavan CP, Diamond J (2007) Origins of major human infectious diseases. Nature 447:279-283

Wolfe ND, Daszak P, Kilpatrick AM, Burke DS (2005) Bushmeat hunting, deforestation, and prediction of zoonotic disease emergence. Emerging Infectious Diseases 11:1822-1827

Worobey M, Gemmel M, Teuwen DE, Haselkorn T, Kunstman K, Bunce M, Muyembe JJ, Kabongo JMM, Kalengayi RM, Van Marck E, Gilbert MTP, Wolinsky SM (2008) Direct evidence of extensive diversity of HIV-1 in Kinshasa by 1960. Nature 455:661-664. doi:10.1038/nature07390

Worobey $\mathrm{M}$, Telfer $\mathrm{P}$, Souqhière $\mathrm{S}$, Hunter $\mathrm{M}$, Coleman CA, Metzger MJ, Reed P, Makuwa M, Hearn G, Honarvar S, Roques P, Apetrei C, Kazanji M, Marx PA (2010) Island biogeography reveals the deep history of SIV. Science 329:1487. doi:10.1126/ science. 1193550 